\title{
Community knowledge, attitudes and behaviors in prevention of COVID-19 transmission: A systematic review
}

\author{
Kholis Ernawati $^{1}$, Istri Bela Cantika ${ }^{2}$, Riska Rahmadita Isaputri ${ }^{3}$, Atika Wahyu Andari ${ }^{4}$, \\ Muhammad Fajar Ramadhan ${ }^{5}$, Shifa Khaunan Nathasia ${ }^{6}$, Rifqatussa'adah ${ }^{7}$, Hayati Sari Hasibuan ${ }^{8}$, \\ Lina Tri Mugi Astuti', Yunita Ismail ${ }^{10}$ \\ 1,2,3,4,5,6,7 Faculty of Medicine, Universitas YARSI, Indonesia \\ ${ }^{8}$ School of Environmental Science, Universitas Indonesia \\ ${ }^{9}$ Indonesian Environmental Scientists Association, Indonesia \\ ${ }^{10}$ Faculty of Engineering, President University, Indonesia
}

\section{Article Info}

Article history:

Received Sep 22, 2020

Revised Dec 23, 2020

Accepted Jan 2, 2021

\section{Keywords:}

Attitude

COVID-19 transmission

Knowledge

Practice

\begin{abstract}
The research objective was to determine the community's knowledge, attitudes, and behavior in preventing the transmission of COVID-19 with a systematic review approach. The research method used the protocol preferred reporting items for systematic review and meta-analysis (PRISMA). The research variables were sociodemographic, knowledge, attitudes, and behaviors to prevent COVID 19. The search process for articles was accessed on three electronic journal databases. The article inclusion criteria are quantitative research, primary data, and year of publication (January-July 2020), in English, open access; have gone through the peer review stage, and full-text articles. A descriptive analysis was carried out on each research variable. The results showed ten articles that fit the inclusion criteria, consisting of $100 \%$ sociodemographic variables, 90\% knowledge, 90\% attitude, and $80 \%$ behavior. The number of articles with significant research results on knowledge variables (covering aspects of disease recognition, modes of transmission, general symptoms, and methods of prevention) was $61.11 \%$ of articles. The number of significant articles on attitude variables (including self-isolation, use of masks, social distancing, COVID-19, and government) was $35.54 \%$. The number of substantial articles on the variable of preventive behavior (including handwashing, social distancing, hand sanitizers, use of masks, and self-isolation) was $45 \%$.
\end{abstract}

This is an open access article under the CC BY-SA license.

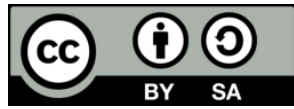

\section{Corresponding Author:}

Kholis Ernawati

Faculty of Medicine

Universitas YARSI

Jalan Letjen Suprapto No. 13, RT10/RW5, Cempaka Putih, Central Jakarta, 10510, Indonesia

Email: kholisernawati2@gmail.com

\section{INTRODUCTION}

Coronavirus disease 2019 (COVID-19) is still the main health problem in the world. The first COVID-19 case, according to a World Health Organization (WHO) report allegedly, first appeared on December 31, 2019, from Wuhan, Hubei Province, China. On January 30, 2020, WHO designated COVID-19 status as a public health emergency of international concern (PHEIC). The increase in the number of COVID-19 cases is happening relatively quickly, and there is already a spread between countries; on March 11, 2020, WHO has designated COVID-19 as a pandemic [1]. The spread of COVID-19 can be 
through direct contact, environment or virus-contaminated objects, airway droplets, and airborne particles [2]. The total global COVID-19 confirmation cases of August 10, 2020, were 19,718,030 cases, with 253,409 cases per day and 729,013 deaths [3].

The main effort in preventing transmission of the disease is the use of face masks in public places, where there can be the transmission of the community [4]. The global strategy for preventing COVID-19 transmission is to mobilize all sectors of government and society to participate in prevention such as hand hygiene, respiratory etiquette, and physical distancing; finding and isolating all cases including providing appropriate care and tracking and quarantine; restrictions on domestic and international travel; reducing mortality by providing proper clinical care and ensuring the health of frontline workers and vulnerable populations; developing safe and effective vaccines and therapies [5].

In Indonesia itself, various efforts are being made to suppress COVID-19 transmission. One of them is to practice social distancing in public, followed by improving public hygiene through regular handwashing. Other measures socialized through various media sources ask people to stay at home, refrain from using public transportation, always wear masks, keep a safe distance from the public while in the crowd, and avoid going to areas with high numbers COVID-19 infections [6]. However, the big problem with social distancing policy is that most Indonesians do not adhere to it. Indonesians still do other activities outside the house, vacation to various places, and return to their hometown [7].

In research conducted by Prakash et al. about perspectives on COVID-19 and global pandemic challenges conducted in New Delhi, India, in 2020 concluded that the community needed to cooperate and participate in the prevention of COVID-19 transmission [8]. Zhong et al. research on the knowledge, attitudes, and behavior of the Chinese population towards COVID-19 during the pandemic period conducted in Hubei, China, in 2020 concluded that health education programs aimed at improving COVID-19 knowledge are helpful for Chinese citizens to maintain an optimistic attitude and maintain appropriate practices [9]. This research aims to examine the community's participation in the prevention of COVID-19 transmission with a systemic review approach.

\section{RESEARCH METHOD}

The research used a systematic review approach based on the preferred reporting items for systematic review and meta-analyses (PRISMA) protocol [10] as seen in Figure 1. The PRISMA protocol is used to identify research articles relevant to COVID-19 transmission prevention practices and includes knowledge, attitude, practice (KAP), and sociodemographic variables. The article search process is accessed on three electronic databases, namely PLOS ONE, Pro-Quest, and Google Scholar. Keywords used in journal article searches are knowledge, attitude, practice, and COVID-19 transmission.

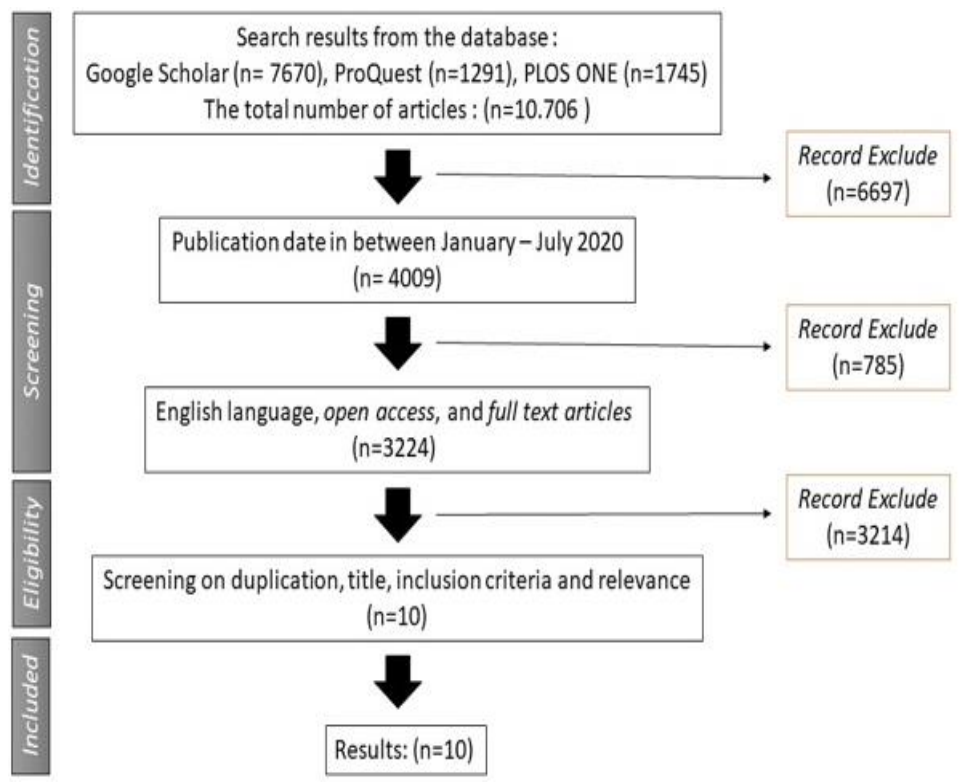

Figure 1. PRISMA protocol 
Community participation is a sincere willingness of the community to help with disease management activities in their respective regions so that the spread of COVID-19 does not expand. Therefore, people with their awareness do social distancing and self-isolation. In this case, participation needs to be distinguished by mobilization that contains elements of coercion or necessity, either by the government or by other parties who have more power [11].

Eligibility studies were conducted using inclusion and exclusion criteria. This review's inclusion criteria are quantitative research, primary data, publication year (January-July 2020), English language, openaccess article, articles that have gone through the peer review stage, full-text articles, and discussion community participation on prevention of COVID-19 transmission. In contrast, this review's exclusion criteria are qualitative research, literature other than articles, literature reviews, and health workers samples. Data extraction is carried out by the flowchart as shown in Figure 1. Furthermore, a narrative descriptive analysis of the study's findings was carried out.

\section{RESULTS AND DISCUSSION}

\subsection{Results}

The selection based on keywords and following PRISMA protocol obtained a total of 10,706 articles, then in screening based on the year of publication (January-July 2020), got a total of 4009 articles. Screening based on English journals, open access, full text, and articles that have gone through peer review stages from PLOS ONE, ProQuest, and Google Scholar, obtained 3224 articles. Eligibility study conducted to eliminate article duplication, articles that are less relevant to the problem and articles that do not comply with the established inclusion criteria. The last stage is obtained as many as ten articles that match the criteria of inclusion. Table 1 illustrates the distribution of factors used in the study in 10 articles of screening results. There are four factors, such as sociodemographic factors discussed in 10 articles (100\%), knowledge and attitude factors each discussed in 9 articles (90\%), and practice factor discussed in 8 articles (80\%).

Table 1. Distribution of articles based on factors used in community participation research

\begin{tabular}{ccc}
\hline Variable & Frequency (article) & Percentage \\
\hline Sociodemographic & 10 & $100 \%$ \\
Knowledge & 9 & $90 \%$ \\
Attitude & 9 & $90 \%$ \\
Practice & 8 & $80 \%$ \\
\hline
\end{tabular}

The number of research samples used and the number of item categories in the aspects assessed by each factor are described in Table 2. The represents a diverse number of research samples, from 201 samples6000 samples as shown in Table 2. The items of the assessment aspect on the factors used in this community research are diverse; only seven studies use these four factors (code 1,2,3,5,6,7,10), sociodemographic, knowledge and attitude in 1 study (code 4), sociodemographic, attitude and practice in 1 study (code 8), sociodemographic and knowledge in 1 study (code 9).

Table 2. Number of sample and assessment items questionnaire on variables used in community participation

\begin{tabular}{|c|c|c|c|c|c|c|}
\hline \multirow[b]{2}{*}{$\begin{array}{l}\text { No } \\
\text { (code) }\end{array}$} & \multirow[b]{2}{*}{ Research (article) } & \multirow[b]{2}{*}{$\begin{array}{l}\text { Research } \\
\text { samples }\end{array}$} & \multicolumn{4}{|c|}{ Questionnaire items on variables } \\
\hline & & & $\begin{array}{c}\text { Sociodemographic } \\
\text { (item) }\end{array}$ & $\begin{array}{c}\text { Knowledge } \\
\text { (item) }\end{array}$ & $\begin{array}{l}\text { Attitude } \\
\text { (item) }\end{array}$ & $\begin{array}{c}\text { Practice } \\
\text { (item) }\end{array}$ \\
\hline 1 & (B. Yanti et al., 2020) [7] & 1146 & 5 & 10 & 10 & 10 \\
\hline 2 & (M. S. Afzal et al., 2020) [12] & 1004 & 9 & 14 & 19 & 11 \\
\hline 3 & (Lau et al., 2020) [13] & 2090 & 6 & 8 & 2 & 6 \\
\hline 4 & (D. Sari et al., 2020) [6] & 201 & 5 & 10 & 10 & NA \\
\hline 5 & (E. Hager et al., 2020) [14] & 1437 & 5 & 20 & 9 & 17 \\
\hline 6 & (Y. Kebede et al., 2020) [15] & 247 & 7 & 14 & 3 & 9 \\
\hline 7 & (A. Azlan et al., 2020) [16] & 4850 & 5 & 13 & 3 & 3 \\
\hline 8 & (H. Seale et al., 2020) [17] & 1420 & 9 & NA & 13 & 10 \\
\hline 9 & (S. Almofada et al., 2020) [18] & 6000 & 5 & 7 & NA & NA \\
\hline 10 & (P. Parikh et al., 2020) [19] & 502 & 3 & 12 & 4 & 11 \\
\hline
\end{tabular}




\subsubsection{Sociodemographic factors}

Table 3 shows some of the sociodemographic aspects studied in community participation. Many elements can be included in this factor, but only four parts are the most studied in almost all research, namely age, gender, education, and employment.

Table 3. Sociodemographic factors in community participation research of COVID-19 transmission

\begin{tabular}{ccccc}
\multicolumn{5}{c}{ prevention } \\
\hline \multirow{2}{*}{ Factors } & Results & & \\
& Category & Code & Freq. & $\%$ Article \\
\hline \multirow{4}{*}{ Age } & Significant & $(2,5,6,7,9)$ & 5 & 50 \\
& Non-sign. & $(8)$ & 1 & 10 \\
& NA & $(1,3,4,10)$ & 4 & 40 \\
& Total & 10 & 100 \\
& Significant & $(5,7,8,9)$ & 4 & 40 \\
Gender & Non-sign. & $(2,6)$ & 2 & 20 \\
& NA & $(1,3,4,10)$ & 4 & 40 \\
& Total & 10 & 100 \\
& Significant & $(2,3,5,6,9)$ & 5 & 50 \\
Education & Non-sign. & $(8)$ & 1 & 10 \\
& NA & $(1,4,7,10)$ & 4 & 40 \\
& Total & 10 & 100 \\
& Significant & $(2,6,7)$ & 3 & 30 \\
Job & Non-sign. & $(8)$ & 1 & 10 \\
& NA & $(1,3,4,5,9,10)$ & 6 & 60 \\
& Total & 10 & 100 \\
\hline Sign: Significan & Freq: frequency & &
\end{tabular}

Age factor provides significant value in $50 \%$ of articles discussing sociodemographic factors. However, different results were found, such as in E. Hager et al. significant at the age of $18-29$, S. Almofada et al. at 25-34, and A. Azlan et al. at the age of 30-49 years [12-14]. The gender is significant in $40 \%$ of different articles (code 7,8) significant in women, while (code 5,9) significant in men. The education factor is significant in $50 \%$ of articles, and the work factor is significant in $30 \%$ of articles.

\subsubsection{Knowledge, attitude, and practice factors}

KAP questionnaire question patterns on COVID-19 transmission prevention are usually categorized in several points: introduction of the disease (knowing about COVID-19 pandemic), transmission, general symptoms, and prevention of transmission. Here are some article assessment results based on the KAP questionnaire's main points in preventing COVID-19 transmission in the form of a table.

Table 4 shows the distribution of aspects of knowledge factors to prevent COVID-19 transmission in community participation research. The most studied aspect and has the highest significant value is the transmission of the COVID-19 element in $77.78 \%$ of articles. They were followed by other factors such as preventing transmission of COVID-19 with a substantial amount in $66.67 \%$ of papers, the introduction of the disease in $55.56 \%$ of papers, and general symptoms knowledge in $44.44 \%$ of papers. The average significant research article on this factor amounted to $61.11 \%$ of papers. Significant results were obtained in all studies that discussed these aspects, except those that did not have a p-value categorized as no available (NA).

Table 4. Knowledge factors in community participation research of COVID-19 transmission prevention

\begin{tabular}{ccccc}
\hline \multirow{2}{*}{ Factors } & Category & Results & & \\
& Code & Freq. & $\%$ Article \\
\hline \multirow{3}{*}{ Introduction of the disease } & Significant & $(2,3,4,5,9)$ & 5 & 55,56 \\
& Non-sign. & - & 0 & 0 \\
& NA & $(1,6,7,10)$ & 4 & 44,44 \\
& Total & & 9 & 100 \\
Transmission of COVID-19 & Significant Non-sign. & $(2,3,4,5,6,7,9)$ & 7 & 77,78 \\
& NA & - & 0 & 0 \\
& Total & $(1,10)$ & 2 & 22,22 \\
& & & 9 & 100 \\
General symptoms & Significant Non-sign. & $(4,5,6,7)$ & 4 & 44,44 \\
& NA & - & 0 & 0 \\
& Total & $(1,2,3,9,10)$ & 5 & 55,56 \\
Prevention of transmission & & 9 & 100 \\
& Significant Non-sign. & $(3,4,5,6,7,9)$ & 6 & 66,67 \\
& NA & - & 0 & 0 \\
& Total & $(1,2,10)$ & 3 & 33,33 \\
& Mean of significant researches & & $61,11 \%$ \\
\hline
\end{tabular}


Table 5 shows the distribution of attitude factors in community participation for the prevention of COVID-19 transmission. Almost all of the aspects provide the same value. In terms of view on COVID-19 (symptoms, information to treatment, and the government's perspective on the handling of COVID-19), each holds the highest percentage of $55.56 \%$, followed by the aspect of the view of self-isolation has the significant result of $22.2 \%$, view on the use of masks $22.2 \%$, views on social distancing $22.2 \%$. The average research articles that have a substantial value on the attitude factor are $35.54 \%$ of articles.

Table 6 shows the distribution of practice (action) factor studies to prevent COVID-19 transmission in community participation research. The most critical aspects studied and the most valuable, are a) washing hands properly using soap and running water, b) maintaining distance, c) doing social distancing, and d) avoiding crowded places. These two aspects are significant in $75 \%$ of the articles. Other factors studied included washing hands properly using a disinfectant/hand sanitizer, using a mask when going out, and selfisolation gave a significant value in $25 \%$ of the articles. The average number of essential studies on practice factors was $45 \%$ of articles.

Table 5. Attitude factors in community participation research of COVID-19 transmission prevention

\begin{tabular}{ccccc}
\hline Factors & & Results & & \\
& Category & Code & Freq. & $\%$ Article \\
\hline \multirow{3}{*}{ View of self-isolation } & Significant & $(2,5)$ & 2 & 22.2 \\
& Non-sign. & $(4)$ & 1 & 11.1 \\
& NA & $(1,3,6,7,8,10)$ & 6 & 66.67 \\
& Total & & 9 & 100 \\
View on the use of masks & Significant & $(5,8)$ & 2 & 22.2 \\
& Non-sign. & $(4)$ & 1 & 11.1 \\
& NA & $(1,2,3,6,7,10)$ & 6 & 66.67 \\
& Total & & 9 & 100 \\
View on social distancing & Significant & $(2,5)$ & 2 & 22.2 \\
& Non-sign. & $(4)$ & 1 & 11.1 \\
& NA & $(1,3,6,7,8,10)$ & 6 & 66.67 \\
& Total & & 9 & 100 \\
& Significant & $(2,3,5,6,8)$ & 5 & 55.56 \\
View on COVID-19 (symptoms, transmission to treatment) & Non-sign. & - & 0 & 0 \\
& NA & $(1,4,7,10)$ & 4 & 44.44 \\
& Total & & 9 & 100 \\
& Significant & $(2,5,6,7,8)$ & 5 & 55.56 \\
& Non-sign. & - & 0 & 0 \\
The government's view on handling COVID-19 & NA & $(1,3,4,10)$ & 4 & 44.44 \\
& Total & & 9 & 100 \\
& & & & 35.54 \\
\hline
\end{tabular}

Table 6. Practice factors in community participation research of COVID-19 transmission prevention

\begin{tabular}{ccccc}
\hline Factors & Category & Code & Freq. & $\%$ Article \\
\hline & Significant & $(2,3,5,6,7,8)$ & 6 & 75 \\
Wash hands properly using soap and running water & Non-sign. & $(1,10)$ & 0 & 0 \\
& NA & & 2 & 25 \\
& Total & & 8 & 100 \\
& Significant & $(2,3,5,6,7,8)$ & 6 & 75 \\
& & - & & \\
& & $(1,10)$ & 0 & 0 \\
Keep the distance, do social distancing and avoid crowded places & Non-sign. & NA & & 25 \\
& Total & 8 & 100 \\
Wash hands appropriately using disinfectant/hand-sanitizer & Significant & $(3,5)$ & 2 & 25 \\
& Non-sign. & - & 0 & 0 \\
& NA & $(1,2,6,7,8,10)$ & 6 & 75 \\
& Total & & 8 & 100 \\
& Significant & $(3,7)$ & 2 & 25 \\
& Non-sign. & - & 0 & 0 \\
& NA & $(1,2,5,6,8,10)$ & 6 & 75 \\
& Total & & 8 & 100 \\
& Significant & $(5,8)$ & 2 & 25 \\
& Non-sign. & - & 0 & 0 \\
& NA & $(1,2,3,6,7,10)$ & 6 & 75 \\
& Total & & 8 & 100 \\
& & & $45 \%$ \\
\hline
\end{tabular}


Table 7 shows the research findings and conclusions of each of the articles used in this paper. The report concludes that most of the respondents indicated that respondents had good knowledge of COVID-19. Some of them got the results that positive ability was correlated with good attitudes and behavior. Not all good experiences had a relationship with good attitudes and actions in preventing the transmission of COVID-19.

Table 7. Research findings of community participation

\begin{tabular}{|c|c|c|}
\hline Research (article) & Findings & Conclusion \\
\hline $\begin{array}{l}\text { (B. Yanti et al., } \\
\text { 2020) [7] }\end{array}$ & $\begin{array}{l}\text { Among respondents who have good knowledge also show a } \\
\text { positive attitude and ethical behavior. }\end{array}$ & $\begin{array}{l}\text { Indonesian society has the knowledge and ethical } \\
\text { behavior and a positive attitude towards social } \\
\text { distancing, which is very accountable for } \\
\text { controlling transmission COVID-19. }\end{array}$ \\
\hline $\begin{array}{l}\text { (M. S. Afzal } e t \\
\text { al., 2020) [12] }\end{array}$ & $\begin{array}{l}\text { The knowledge of COVID-19 is positively correlated with } \\
\text { attitude and practice during a pandemic. }\end{array}$ & $\begin{array}{l}\text { The community must improve the knowledge, } \\
\text { attitudes, and practices of COVID-19 among the } \\
\text { illiterate or undereducated communities. }\end{array}$ \\
\hline $\begin{array}{l}\text { (Lau et al., 2020) } \\
{[13]}\end{array}$ & $\begin{array}{l}\text { Preventive measures are carried out by respondents who } \\
\text { have sufficient knowledge of the transmission of COVID-19. }\end{array}$ & $\begin{array}{l}\text { Directed health education and specific instructions } \\
\text { for a response to public health should be } \\
\text { developed carefully due to an extreme lack of } \\
\text { household income. }\end{array}$ \\
\hline $\begin{array}{l}\text { (D. Sari et al., } \\
\text { 2020) [6] }\end{array}$ & $\begin{array}{l}\text { Most of them have adequate knowledge and positive } \\
\text { attitudes towards the COVID-19 pandemic. Respondents } \\
\text { have a terrible attitude in two aspects: not maintaining } \\
\text { distance/ social distancing, not diligently exercising/eating } \\
\text { nutritious foods. }\end{array}$ & $\begin{array}{l}\text { The prevention of COVID- } 19 \text { transmission will } \\
\text { not be maximized and effective by merely } \\
\text { publishing the number of cases per day in the } \\
\text { general public. }\end{array}$ \\
\hline $\begin{array}{l}\text { (E. Hager et al., } \\
\text { 2020) [14] }\end{array}$ & $\begin{array}{l}\text { Most of them know about preventing transmission and have } \\
\text { a positive attitude towards COVID-19, but not more than } \\
\text { half of the respondents have carried out all health protocols. }\end{array}$ & $\begin{array}{l}\text { Compliance with health regulations needs to be } \\
\text { improved, and governments to effectively } \\
\text { implement standard infection and prevention } \\
\text { measures. }\end{array}$ \\
\hline $\begin{array}{l}\text { (Y. Kebede et al., } \\
\text { 2020) [15] }\end{array}$ & $\begin{array}{l}\text { Most of them know about prevention of transmission, but a } \\
\text { negative attitude towards COVID- } 19 \text { and practicing } \\
\text { handwashing as a prevention measure is the most widely } \\
\text { practiced. }\end{array}$ & $\begin{array}{l}\text { Public education efforts must be based on an } \\
\text { appropriate knowledge building level to raise self- } \\
\text { awareness of high risk. }\end{array}$ \\
\hline $\begin{array}{l}\text { (A. Azlan et al., } \\
\text { 2020) [16] }\end{array}$ & $\begin{array}{l}\text { There is a similarity of positive results regarding knowledge } \\
\text { and attitudes towards COVID-19, but it is inversely } \\
\text { proportional to the practice. Namely, there is still little } \\
\text { practice in using face masks. }\end{array}$ & $\begin{array}{l}\text { The government, the health authorities, needs to } \\
\text { improve health education programs tailored to the } \\
\text { community's knowledge, attitudes, and behavior. }\end{array}$ \\
\hline $\begin{array}{l}\text { (H. Seale et al., } \\
\text { 2020) [17] }\end{array}$ & $\begin{array}{l}\text { Half of the respondents felt COVID-19 would 'slightly' } \\
\text { affect their health if infected, and only a few considered their } \\
\text { risk level was high or very high. }\end{array}$ & $\begin{array}{l}\text { Supporting people's understanding of the } \\
\text { prevention of COVID-19 transmission and } \\
\text { instilling their confidence is necessary. }\end{array}$ \\
\hline $\begin{array}{l}\text { (S. Almofada et } \\
\text { al., 2020) [18] }\end{array}$ & $\begin{array}{l}\text { Most of the population respondents reported awareness of } \\
\text { COVID-19 (virus, symptoms, incubation). }\end{array}$ & $\begin{array}{l}\text { The population of Saudi Arabia has a basic } \\
\text { knowledge of the modes of transmission, how to } \\
\text { protect themselves from the virus, and the age } \\
\text { groups at risk of catching the virus. }\end{array}$ \\
\hline $\begin{array}{l}\text { (P. Parikh et al., } \\
\text { 2020) [19] }\end{array}$ & $\begin{array}{l}\text { Most of the heart symptoms of COVID-19 and have been } \\
\text { practicing how to prevent transmission in everyday life. }\end{array}$ & $\begin{array}{l}\text { The general public has taken a good look at } \\
\text { COVID-19 and has taken adequate steps to } \\
\text { prevent its spread. }\end{array}$ \\
\hline
\end{tabular}

\subsection{Discussion}

Based on the article screening's result using the PRISMA protocol of the ten quantitative research, Table 1 describes the distribution of articles based on factors used, while Table 2 describes the questionnaire items and the distribution of the elements used in the report. Tables 3-6 describe each of the factors and Table 7 describes the finding on the systematic review.

This study has many limitations, such as the scale took not limiting the country or continent and limiting the number of samples so that the results provide high heterogeneity. The authors do not determine the quantitative study design to get more information, but there is only a cross-sectional study design. The results presentation presented in Tables 3-6 illustrates the percentage amount of articles from each study's significant aspects.

Table 2 describes the distribution of the sample and the factors used in community participation research. The articles associate various factors, such as those in S. Almofada et al. correlate sociodemographic aspects with knowledge in the form of basic knowledge about modes of transmission and self-prevention from viruses [18]. Sociodemographic characteristics related to knowledge and attitude factors, as in D. Sari et al. aim to see the general public's understanding and attitudes regarding COVID-19 that can provide insight into the effectiveness of preventive measures pandemic [6]. In H. Seale et al.'s article correlates sociodemographic aspects with attitude and practice factors, namely the views and behavior of hygiene and avoidance in the COVID-19 pandemic, also the willingness and capacity to engage with these 
mitigation measures [17]. The sociodemographic aspects associated with the three KAP factors in E. Hager et al., Y. Kebede et al., A. Azlan et al., and P. Parikh et al. evaluated people's understanding, attitudes, and behavior about COVID-19 so that an effective transmission prevention strategy can be created with considering the awareness of the society itself [14-16, 19]. B.Yanti et al.'s research aimed at identifying people's knowledge, attitudes, and behavior against social distancing as a means of preventing the transmission of COVID-19 [7]. The present study's findings suggested that the demographic factors are associated with KAP towards COVID-19, as were previously found on severe acute respiratory syndrome (SARS) studies in 2003 [20, 21]. Research with these four factors (sociodemographics and KAP) would help provide better insights into the development of prevention strategies and health promotion programs, which is by understanding their KAPs during the early stages of an emerging pandemic, can help government departments and multi-lateral organizations response and communication strategies appropriately [16, 22]. Based on the previous study, assessing the KAP of respondents and further education of the general public has proved effective in changing the populace's risk perception and resulted in attitudinal changes that were necessary to reduce the epidemic disease burden [23].

Table 3 describes the sociodemographic factors. In terms of age, it gives significant results in 50\% of articles or as many as five items (codes $2,5,6,7,9)$, but not have an expected value because the period in E. Hager et al.'s article is significant at 18-29 years, S. Almofada et al. at the age of 25-34 years and A. Azlan et al. at the age of 30-49 years [12-14]. According to E. Hager et al.'s article, the older the respondents, the better their attitude against these diseases [14]. This result aligns with the findings from Singapore and Hong Kong during the 2003 SARS outbreak [24, 25], and some studies during the 2009 H1N1/A pandemic [26, 27], which said that older age was associated with the adoption of precautionary behaviors. However, according to Y. Kebede et al., the respondents aged between 30 and 49 had a lower average of multidimensional knowledge (MDK) scores than younger respondents [15]. Gender aspect is significant in $40 \%$ different articles, as in A. Azlan et al. and H. Seale et al. were significant in women, whereas E. Hager et al. and S. Almofada et al. were significant in men [12-15]. According to E. Hager et al.'s article in terms of gender, it was found that women were more likely to perform prevention and avoidance behaviors than men [14]. These age and gender differences in the significant result articles are possibly due to an unbalanced sample distribution. According to Srichan, women and younger adults were more likely to have an adequate level of preparedness for COVID-19 prevention and control [28].

In the educational aspect, 50\% articles show significance (i.e., code articles 2, 3, 5, 6, 9). The article M. S. Afzal et al., E. Hager et al. and the article of S. Almofada et al. research results are significant at the postgraduate level, while at Lau et al., significant at the level of primary school education and in Y. Kebede et al. significant for junior and senior high school students [12-13, 16, 18-19]. The relationship between health and education does not depend on whether health is identified as health status or health behavior, but it is clear that well-educated people are healthier and always engage in healthier behavior [29].

In the aspect of the profession, the significant value was found in $30 \%$ of the articles, namely M. S. Afzal et al., Y. Kebede et al., and A. Azlan et al. $[12,15,16]$. According to Y. Kebede et al. respondents who work as farmers have a lower average MDK score than those who work as private/ government businesses and students, while the unemployed have lower mean than farmers [15].

S. Notoatmodjo suggests that knowledge or cognitive is a domain that is essential for the formation of one's actions, so it can be said that learning about the prevention of COVID-19 transmission should be a factor that significantly affects efforts to prevent the transmission of COVID-19 [30]. Individuals who have information will determine how to react and make decisions when encountering a problem [31]. Additionally, confusion surrounding necessary information and knowledge on reducing transmission and exposure to the virus puts people at risk of infection [32, 33]. The research by E. Hager et al., A. Azlan et al., and S. Almofada et al. were respondents have sufficient knowledge of COVID-19 [12-14]. Research by M. S. Afzal et al., Lau et al., and D.Sari et al. showed that the increase of knowledge regarding COVID-19 by the aspects in Table 4 could improve perceptions and expected behavior, such as washing hands frequently to prevent transmission of COVID-19 [6, 12, 13]. However, there is a massive gap between the amount of knowledge about preventive methods and behavior. For example, only $77.3 \%$ of respondents reported washing their hands frequently with water and soap, although the knowledge was as high as $95.5 \%$ [15]. Besides that, according to the research by M. S. Afzal et al. and A. Azlan et al., good knowledge of COVID-19 was associated with an optimistic attitude, and the right practices against COVID-19 shows that health education program that aims to increase knowledge of COVID-19 helps encourage optimism and determine best practice $[12,16]$. This result is in line with Lau et al., where the population who has limited access to health services and information can affect prevention attitudes and behavior [13]. This matter provides an overview of the need to strive to provide information and motivate people if they want to carry out activities to increase knowledge on the prevention of COVID-19 transmission. At present, social media plays a vital role as a source of information due to providing information more quickly and allowing for the free disclosure of 
knowledge; it appears that television is considered a source of accurate and trustworthy information by the general public [34-36]. Adequate monitoring of social media platforms to confirm and improve the quality of news delivered to the people is of prime importance [37]. The consistent message from government or health authorities is the key to assisting the public's knowledge and understanding of COVID-19 [16].

Attitude is a tendency that has not been accompanied by concrete actions towards behavior [38]. Attitude has three main components, i.e., awareness, feelings, and behavior [39]. Two factors can influence the formation of an attitude. First, people can quickly receive information (knowledge). Second, thinking about a problem can increase the tendency to form an attitude [40]. Based on data from Table 5, the nine articles which discuss aspects of attitude factor in community participation for the prevention of COVID-19 transmission shows that the most significant results are found in two aspects, including the view of COVID-19 (symptoms, transmission, and treatment) and the government's idea of handling COVID-19 which both amounted to 5 articles (55.56\%) with different articles. The view of COVID-19 in question is found in the research of Lau et al., namely in the form of public concern about COVID-19 transmission, how they react if they showed the signs and symptoms of COVID-19, how to handle treatment if one of them shows these symptoms and the awareness to do an examination to the hospital [13].

In some cases, awareness of treatment in society is still lacking because some people want to get free treatment according to the study of Afzal et al. where almost the majority of respondents want to get free treatment and vaccination for COVID-19 [12]. Based on several other studies, the view of COVID-19 is in Kebede et al., Seale et al. and Hager et al.'s articles, namely the perspective on the impact of asymptomatic patients, self-efficacy to control COVID-19, positive attitude towards protection and prevention of COVID-19 from WHO [14-15, 17]. Based on research, the government's view of COVID-19 also holds a significant percentage in this attitude's aspect, among others, in the study of Azlan et al. regarding their beliefs towards the government and the government's ability to deal with COVID-19 [16]. On several other studies also explain the form of views on government efforts in regulating international flights and stabilizing the economy during pandemics, positive attitudes for the protection actions of local health authorities, the stigma of COVID-19 arise in society, as well as the effectiveness of regulations promoted by the government $[12,14,15,17]$. Fear of being socially marginalized and stigmatized due to a disease outbreak may cause people to deny early clinical symptoms and may contribute to their failure to seek timely medical care [41]. The overall attitude factor provides an average score of $35.54 \%$, which holds a lower percentage than the average value of knowledge and practice. According to Erfani, age, being male, having a lower level of education, being single, and having a higher household number were significantly associated with having a lower attitude towards COVID-19 [42].

Table 6 discusses factors of COVID-19 prevention practice (action) in community participation research. An expected effort is a form of behavior in preventing transmission during the COVID-19 pandemic. According to Notoatmodjo, health behavior is a person's (organism) response to stimuli related to illness and disease, the health service system, food, and the environment. Health behavior includes health prevention behavior, which is a response to prevent infection [30]. According to Bandura social cognitive theory, an individual's self-efficacy plays a crucial role in the individual's likelihood to engage in the desired behavior. If an individual does not believe that she/he can carry out the behavior, there is little motivation to engage [43]. In the absence of any pharmaceutical intervention, the only strategy against COVID19 is to reduce the mixing of susceptible and infectious people through early ascertainment of cases or reduction of contact, how individual and community actions can help mitigate and manage the costs of an epidemic $[44,45]$. Hand hygiene is one of the most effective measures that can be taken to reduce the spread of pathogens and prevent infection with the COVID-19 virus [46]. Proper handwashing with soap and running water gave significant results in six out of eight articles (75\%), while washing hands properly using a disinfectant/hand sanitizer was only significant in two out of eight articles (25\%). According to Lau et al., the relatively low proportion of preventive behavior indicates the need to increase public health knowledge that may not have regular access to information and other barriers such as low-income populations [13]. Droplets produced by coughing and sneezing are the primary sources of influenza transmission. Thus social distancing can reduce the risk of person-to-person transmission at a distance of 3-6 feet [47]. Maintaining distance, doing social distancing, and avoiding crowded places showed significant results in 6 out of 8 articles (75\%) in the study of Kebede et al. respondents who reported avoiding crowded places were $33.2 \%$, although knowledge of this behavior was $90.3 \%$.

Targeted social distancing may be promoted by governments and public health bodies as a strategy for controlling epidemics, for example, in the form of school or workplace closures [48]. There may be specific reasons why it is not easy for people to avoid crowded places. For example, the living conditions with a high population, social and religious ceremonies from each country, and high unemployment rates bridge the gap between knowledge and behavior [15]. Using a mask when going out and doing self-isolation gave significant results in 2 out of 8 articles (25\%). According to Azlan et al. the use of masks has not 
become the norm in society, and also the emergence of COVID-19 has led to an increase in demand for medical masks (and hand-sanitizers) in every country so that the supply is limited [16].

The study and conclusions of the article can be found in Table 7. From these results, it was found that many respondents had good knowledge of COVID-19. Some of them conclude that actual knowledge correlates with the right attitude and behavior [7, 17-19]. It was then found that a population of respondents actively reported awareness of COVID-19 (virus, symptoms, incubation) [18]. Based on previous research, a relationship exists between knowledge and attitudes in dealing with the COVID-19 pandemic, where an attitude is a predisposition to action and readiness to react in particular environmental objects [49-51]. However, not all of the respondents' good knowledge has a relationship with good attitudes and behavior. Some of them do not practice transmission prevention behavior such as not maintaining social distancing, not washing hands, not wearing face masks, or complying with health protocols [6, 14-16]. Only a small proportion of researchers found that respondents with a poor understanding felt that COVID-19 would only slightly affect their health [17]. The discovery of a new infectious disease may increase motivational pressures and change the level of behavior, depending on various factors such as the current information about a condition (knowledge) [44, 52].

\section{CONCLUSION}

Knowledge is one of the factors that encourage public participation to prevent transmission of COVID-19. The knowledge aspect assessed is the disease (knowing the COVID-19 pandemic), modes of transmission, common symptoms, and prevention of transmission.

Preventive behavior is an essential aspect of community participation efforts to reduce transmission during the COVID-19 pandemic. Preventive behavior is also related to the knowledge and attitudes of each community. In most studies, the three aspects of KAP have a positive relationship/correlation, thus indicating that adequate public knowledge has a positive impact on attitudes towards preventive measures and behavior towards responses to reduce virus transmission. The results of a good KAP aspect can provide direct output, namely a reduction in the incidence of COVID-19 in each country in a specific time and the long term.

This article also provides findings from each item that can be used as a reference for further research. The author hopes that further research can reduce the limitations of this study. Also, this study's results can be used by relevant stakeholders in health education activities for the public regarding preventing COVID-19 transmission to make it more effective and efficient.

\section{ACKNOWLEDGEMENTS}

Thanks to YARSI University for providing support so that this article can be published.

\section{REFERENCES}

[1] Kemenkes RI, "Guidelines for the Prevention and Control of Corona Virus Disease (COVID-19)/Pedoman Pencegahan dan Pengendalian Corona Virus Disease (COVID-19)," 2020.

[2] Z. Wang, W. Qiang, and H. Ke, "A Handbook of 2019-nCoV Pneumonia Control and Prevention," Hubei Science and Technology Press, 2020.

[3] WHO, "Coronavirus disease (COVID-19) Situation Report - 203," A A Pract., vol. 14, no. 6, p. e01218, 2020, doi: 10.1213/xaa.0000000000001218.

[4] World Health Organization, "SARS-CoV-2 transmission: implications for infection prevention precautions/ Transmisi SARS-CoV-2 : implikasi terhadap kewaspadaan pencegahan infeksi," Pernyataan keilmuan, pp. 1-10, 2020, [Online]. Available: who.int.

[5] World Health Organization, “Covid-19 strategy update," no. April, p. 18, 2020, [Online]. Available: who.int.

[6] D. K. Sari, R. Amelia, R. Dharmajaya, et al., "Positive Correlation Between General Public Knowledge and Attitudes Regarding COVID-19 Outbreak 1 Month After First Cases Reported in Indonesia," Journal Community Health, 2020, doi: 10.1007/s10900-020-00866-0.

[7] B. Yanti, et al., "Community Knowledge, Attitudes, and Behavior Towards Social Distancing Policy As Prevention Transmission of COVID-19 in Indonesia," Journal Administrasi Kesehatan Indonesesia, vol. 8, no. 2, p. 4, 2020 , doi: 10.20473/jaki.v8i2.2020.4-14.

[8] P. and R. R. Shyam Prakash, Akanksha Priya, "Current perspective of COVID-19 in India and a global pandemic challenges," International Journal Public Health Clininal Science., vol. 7, no. 3, pp. 111-128, 2020.

[9] B. L. Zhong, et al., "Knowledge, attitudes, and practices towards COVID-19 among Chinese residents during the rapid rise period of the COVID-19 outbreak: A quick online cross-sectional survey," International Journal Biological Science, vol. 16, no. 10, pp. 1745-1752, 2020, doi: 10.7150/ijbs.45221.

[10] L. Shamseer, et al., "Preferred reporting items for systematic review and meta-analysis protocols (PRISMA-P) 2015: Elaboration and explanation," BMJ, vol. 349, no. January, pp. 1-25, 2015, doi: 10.1136/bmj.g7647. 
[11] M. Mulyadi, "Community Participation in Handling the Spread of COVID-19/Partisipasi Masyarakat Dalam Penanganan Penyebaran COVID-19," Info Singkat, Pus. Penelit. Badan Keahlian DPR RI, vol. 12, no. 8, pp. 13$18,2020$.

[12] M. S. Afzal, et al., "Community-Based Assessment of Knowledge, Attitude, Practices and Risk Factors Regarding COVID-19 Among Pakistanis Residents During a Recent Outbreak: A Cross-Sectional Survey," Journal Community Health, no. 0123456789, pp. 1-11, 2020, doi: 10.1007/s10900-020-00875-z.

[13] L. L. Lau, et al., "Knowledge, attitudes and practices of COVID-19 among income-poor households in the Philippines: A cross-sectional study," Journal Global Health, vol. 10, no. 1, pp. 1-11, 2020, doi: 10.7189/JOGH.10.011007.

[14] E. Hager, I. A. Odetokun, O. Bolarinwa, et al., "Knowledge, attitude, and perceptions towards the 2019 Coronavirus Pandemic: A bi-national survey in Africa," PLoS One, vol. 15, no. 7, p. e0236918, 2020, doi: 10.1371/journal.pone.0236918.

[15] Y. Kebede, Y. Yitayih, Z. Birhanu, S. Mekonen, et al., "Knowledge, perceptions and preventive practices towards COVID-19 early in the outbreak among Jimma university medical center visitors, Southwest Ethiopia," PLoS One, vol. 15, no. 5, pp. 1-15, 2020, doi: 10.1371/journal.pone.0233744.

[16] A. A. Azlan, M. R. Hamzah, T. J. Sern, et al., "Public knowledge, attitudes, and practices towards COVID-19: A cross-sectional study in Malaysia," PLoS One, vol. 15, no. 5, pp. 1-15, 2020, doi: 10.1371/journal.pone.0233668.

[17] H. Seale, et al., "COVID-19 is rapidly changing: Examining public perceptions and behaviors in response to this evolving pandemic," PLoS One, vol. 15, no. June 6, pp. 1-13, 2020, doi: 10.1371/journal.pone.0235112.

[18] S. K. Almofada, et al., "Knowledge, Attitudes, and Practices Toward COVID-19 in a Saudi Arabian Population: A Cross-Sectional Study," Cureus, vol. 12, no. 6, p. e8905, 2020, doi: 10.7759/cureus.8905.

[19] P. A. Parikh, et al., "COVID-19 Pandemic: Knowledge and Perceptions of the Public and Healthcare Professionals," Cureus, vol. 12, no. 5, 2020, doi: 10.7759/cureus.8144.

[20] N. Duell, L. Steinberg, G. Icenogle, J. Chein, N. Chaudhary, and L. Di Giunta, "Age patterns in risk taking across the world," Journal Youth Adolescence, vol. 47, no. 5, pp. 1052-1072, 2018.

[21] X. Zhang, Y. Sun, D. Ye, Z. Sun, H. Su, J Ni, "Analysis on mental health status of community residents in Hefei during SARS spread," Chinese J. Dis. Control Prev., vol. 7, pp. 280-282, 2003.

[22] N. M. Ferguson, et al., "Impact of non-pharmaceutical interventions ( NPIs ) to reduce COVID-19 mortality and healthcare demand," Imp. Coll. London, no. March, pp. 1-20, 2020, doi: 10.25561/77482.

[23] C. J. M. Koenraadt, W. Tuiten, R. Sithiprasasna, U. Kijchalao, et al., "Dengue knowledge and practices and their impact an aedes aegypti populations in kamphaeng phet, Thailand," Americal Journal Tropical Medicine Hygine, vol. 74, no. 4, pp. 692-700, 2006, PMID: 16607007.

[24] G. Leung, T. Lam, L. Ho, et al., "The impact of community psychological responses on outbreak control for severe acute respiratory syndrome in Hong Kong," Journal Epidemiology Community Health, vol. 57, p. 857, 2003, doi: 10.1136/jech.57.11.857.

[25] J. Lau, X. Yang, H. Tsui, J. Kim, "Monitoring community responses to the SARS epidemic in Hong Kong: from day 10 to day 62," Journal Epidemiology Community Health, vol. 57, p. 864, 2003, doi: 10.1136/jech.57.11.864.

[26] H. Marshall, P. Ryan, D. Roberton, et al., "Pandemic influenza and community preparedness," American Journal Public Health, vol. 2, no. 2, pp. 365-71, 2009, doi: 10.2105/AJPH. 2008.153056.

[27] B. Cowling, D. Ng, D. Ip, et al., "Community psychological and behavioral responses through the first wave of the 2009 influenza A(H1N1) pandemic in Hong Kong," Journal Infectious Disease, vol. 202, no. 6, pp. 867-76, 2010, doi: $10.1086 / 655811$.

[28] P. Srichan, et al., "Knowledge, attitudes and preparedness to respond to COVID-19 among the border population of northern Thailand in the early period of the pandemic: a cross- sectional study," WHO South-East Asia Journal Public Health., vol. 9, no. September, pp. 118-125, 2020, doi: 10.4103/2224-3151.294305.

[29] A. J. Cowell, "The relationship between education and health behavior: Some empirical evidence," Health Econ., vol. 15, no. 2, pp. 125-146, 2006, doi: 10.1002/hec.1019.

[30] S. Notoatmodjo, "Health Promotion \& Behavioral Sciences /Promosi Kesehatan \& Ilmu Perilaku," Jakarta: Rineka Cipta, 2014.

[31] Ahmadi, "Public health, theory and application/Kesehatan masyarakat, teori dan aplikasi," Penerbit Rajawali Pers, 2013.

[32] K. G. Betford J, Enria D, Giesecke J, Heymann DL, Ihekweazu C, "COVID-19: towards controlling of a pandemic," Lancet, vol. 395, no. January, pp. 1015-8, 2020, doi: 10.1056/NEJMoa2002032.9.

[33] L. Garrett, "COVID-19: the medium is the message," Lancet, vol. 395, no. January, pp. 942-3, 2020.

[34] C. K. L. Pastor, "Sentiment Analysis on Synchronous Online Delivery of Instruction due to Extreme Community Quarantine in the Philippines caused by COVID-19 Pandemic," Asian Journal Multidisciplinary Studies, vol. 3, no. 1, pp. 1-6, 2020.

[35] Y. Shi, et al., "Knowledge and attitudes of medical staff in Chinese psychiatric hospitals regarding COVID-19," Brain, Behaviour, Immunity-Health., vol. 4, no. March, 2020, doi: 10.1016/j.bbih.2020.100064.

[36] P. Geldsetzer, "Knowledge and perceptions of COVID-19 among the general public in the United States and the United Kingdom: A cross-sectional online survey," Annals of Internal Medicine, vol. 15, no. March, pp. 1-4, 2020, doi: 10.1101/2020.03.13.20035 568.

[37] A. Finset, H. Bosworth, P. Butow, P. Gulbrandsen, R. Hulsman, and A. Pieterse, "Effective health communicationa key factor in fighting the COVID-19 pandemic," Patient Eduction Counseling, vol. 103, no. January, pp. 873876, 2020, doi: 10.1016/j.pec.2020.03.027. 
[38] R. J. Glass, “Targeted social distancing design for pandemic influenza," Emerging Infectious Diseases, vol. 12, no. 11, pp. 1671-81, 2006, doi: 10.3201/eid1211.060255.

[39] S. P. Robbins, "Organizational behavior/Perilaku Organisasi, Jakarta: Salemba Empat, 2007.

[40] D. Albarracin, "Theories of reasoned action and planned behavior as models of condom use: A meta-analysis," Psychology Bulletin, vol. 127, no. 1, pp. 142-161, 2001, doi: 10.1037/0033-2909.127.1.142.

[41] B. Person, F. Sy, K. Holton, B. Govert, et al., "Fear and Stigma: The Epidemic within the SARS Outbreak," Emerging Infectious Diseases, vol. 10, no. 2, pp. 358-363, 2004.

[42] A. Erfani, R. Shahriarirad, K. Ranjbar, "Knowledge , Attitude and Practice toward the Novel Coronavirus (COVID-19 ) Outbreak: A Population-Based Survey in Iran," Bulletin World Health Organization, no. March, 2020, doi: 10.2471/BLT.20.256651.

[43] A. Bandura, "Social Cognitive Theory and Exercise of Control over HIV Infection," DiClemente RJ, Peterson JL, Ed. Prev. AIDS Theor. Methods Behav. Interv. Boston, MA Springer US, pp. 25-59, 1994.

[44] J. A. Lewnard, N. C. Lo, "Scientific and ethical basis for social-distancing interventions against Covid-19," Lancet Infectious Disease Elsevier Ltd, vol. 20, no. January, pp. 1-2, 2020, doi: 10.1056/NEJMoa2002032.5.

[45] T. C. Reluga, "Game Theory of Social Distancing in Response to an Epidemic," PLoS Computational Biology, vol. 6, no. 5, pp. 1-9, 2010, doi: 10.1371/journal.pcbi.1000793.

[46] WHO, "WHO Save Lives : Clean Your Hands In The Context Of COVID-19," no. May, pp. 19-20, 2020.

[47] F. Ahmed, N. Zviedrite, A. Uzicanin, "Effectiveness of workplace social distancing measures in reducing influenza transmission: A systematic review," BMC Public Health, vol. 18, no. 518, pp. 1-13, 2018, doi: 10.1186/s12889018-5446-1.

[48] S. Maharaj, A. Kleczkowski, "Controlling epidemic spread by social distancing : Do it well or not at all," BMC Public Health, vol. 12, no. 679, pp. 1-16, 2012, doi: 10.1186/1471-2458-12-679.

[49] M. Salman, Z. Ul, M. Noman, H. Abbas, and Z. Khalid, "Knowledge, attitude and preventive practices related to COVID - 19: a cross - sectional study in two Pakistani university populations," Drugs Therapy Perspectives, no. March, 2020, doi: 10.1007/s40267-020-00737-7.

[50] J. Kumar, M. S. Katto, A. A. Siddiqui, B. Sahito, M. Jamil, and N. Rasheed, "Knowledge, attitude, and practices of healthcare workers regarding the use of face mask to limit the spread of the new coronavirus disease (COVID-19)," Cureus, vol. 12, no. 4, pp. 1-8, 2020.

[51] I. Azjen, "Perceived Behavioral Control, Self-Efficacy, Locus of Control, and the Theory of Planned Behavior," Journal Applied Social Psychology, vol. 32, no. 4, pp. 665-683, 2002, doi: 10.1111/j.1559-1816.2002.tb00236.x.

[52] K. A. Pawelek, C. Salmeron, S. Del Valle, "Connecting within and between-hosts dynamics in the influenza infection-staged epidemiological models with behavior change," Journal Coupled System Multiscale Dynamic., vol. 3, no. 3, pp. 233-243, 2015.

Int. J. Public Health Sci. Vol. 10, No. 1, March 2021: 16-26 